\title{
ÖRGÜTSEL ADALET ALGISININ DUYGUSAL EMEK ÜZERINE ETKİSI: SAĞLIK ÇALIŞANLARI ÜZERİNE BİR ARAŞTIRMA
}

\author{
Yrd. Doç. Dr. Ferda ÜSTÜN \\ Nevşehir Hacı Bektaş Veli Üniversitesi, İ̈BF, (ferdakervanci@gmail.com)
}

\begin{abstract}
ÖZET
Sağllk sektörü üzerine yapılan bu araştırmanın amacı să̆llk çalışanlarının örgütsel adalet algılarının duygusal emek davranışları üzerindeki etkisini belirlemektir. Araştırmada bă̆ımlı ve bă̆ımsız de ğişkenlerin birbiri ile ilişkileri, ortaya konulan hipotezler vasıtası ile incelenmiştir. Araştırma sonucunda örgütsel adalet algısı ile duygusal emek arasında pozitif yönlü orta kuvvette bir korelasyon tespit edilmiştir. Yine duygusal emeğin tüm alt boyutları ile örgütsel adaletin tüm alt boyutları arasında pozitif yönlü dïşük kuvvette bir korelasyon tespit edilmiştir. Örgütsel adaletin duygusal emek üzerine etkisini tespit etmek için çoklu regresyon analizi yapılmış ve dă̆ıtım adaletinin yüzeysel rol davranışı ve derin rol davranışı üzerinde anlamll etkiye sahip olduğ u tespit edilmiştir.
\end{abstract}

Anahtar Kelimeler: Örgütsel Adalet, Duygusal Emek, Sağlık Çalışanları.

\section{THE EFFECT OF ORGANIZATIOAL JUSTICE PERCEPTIONS ON EMOTIONAL LABOUR: A RESEARCH ON HEALTH WORKERS}

\begin{abstract}
The purpose of this research is conducted on health workers to determine the effects of the organizational justice perceptions on emotional labour. The relationships between dependent and independent variables were examined through the suggested hypotheses. As a result a positive and medium significant correlation was found between the organizational justice perceptions and emotional laboring. Additionally, positive and low significant correlation was found between the all sub-dimensions of organization justice perceptions and all subdimensions of emotional labour. Multiple linear regression analysis was conducted to determine the effects on emotional labor of organizational justice perception and the distribution justice have significant effect on surface role behavior and deep role behavior.
\end{abstract}

Keywords: Organizational Justice, Emotional Labour, Health Workers. 


\section{Giriş}

Biyolojik-psikolojik ve sosyolojik bir bütün olan insan karmaşık ve dinamik yapısı gereği duygularından ayrı düşünülemez. Günümüzde hizmet sektörünün gelişimi ile birlikte çalışanların değer, tutum, inanç ve duygularına gösterilen ilgi de artmıştır. Karmaşık bir bütün olan insanın olumlu davranışlarını pekiştirmek ve pozitif çıktılar elde edebilmek adına yöneticiler çalışanlarının adalet, eşitlik ve güven algılarını yükseltmelidir. Çeşitli araştırmalar vasıtası ile bireylerin adalet algıları (Schmiesing, Safrit \& Gliem, 2003) ile örgütsel bağlılık (Folger \& Konovsky, 1989; Barling \& Michelle, 1993; Malatesta \& Byrne, 1997; Simons \& Roberson, 2003; Polat, 2007; Arslantaş \& Pekdemir, 2007; İşcan \& Sayın, 2010) iş tatmini (Begley vd., 2006; Yıldız, 2014; Thomas \& Nagalingappa, 2012) örgütsel vatandaşlık davranışı (Niehoff \& Moorman, 1993; Begley vd., 2006; Çetinkaya \& Çimenci, 2014) örgütsel güven (Bos, 2001; Kickul vd., 2005; Ali \& Jan, 2012; Yıldız, 2014) arasındaki ilişkiler tespit edilmiştir. Yine örgütsel adaletin duygusal emek davranışlarına etkisi son yılların önemli konuları arasında yer almaktadır (Ashforth \& Humphrey, 1995; Morris \& Feldman, 1996; Grandey, 2000; Rupp \& Spencer, 2006; Öz, 2007; Martinez-Inigo vd. 2007; Rupp, McCance, Spencer \& Sonntag, 2008; Spencer \& Rupp, 2009; Barger, 2009; Cosette \& Hess, 2009; Çaldağ, 2010; Değirmenci, 2010; Yürür vd., 2011; Lam \& Chen, 2012; Akbıyık, 2013; Keleş, 2014; Beğenirbaş \& Turgut, 2014; Kızanlıklı, 2014; Keleş \& Tuna, 2016). Sağlık sektöründe emek yoğun çalışan bireylerin duygusal tepkilerini kabul edilebilir bir şekilde yansıtmak adına harcadıkları çaba üzerinde adalet algılarının her hangi bir etkiye sahip olup olmadığının belirlenmesi araştırmanın amacını oluşturmaktadır. Yukarıda da değinildiği gibi örgütsel adalet algısı ile duygusal emek arasındaki ilişkiler birçok araştırmada incelenmiştir. Ancak işbirliği, uyum ve duygusal tutarlılığın büyük önem arz ettiği acil sağlık hizmetleri istasyonları çalışanları üzerine yapılan bu çalışmanın, verilen tedavi ve bakım hizmetlerinin etkinlik ve kalitesinin arttırılmasında yönetici ve uygulayıcılara yol göstereceği düşüncesi bu araştırmayı özgün kılmaktadır. Bu doğrultuda araştırmada acil sağlık hizmeti sunan çalışanların, örgütsel adalet algılarının duygusal emek davranışlarını nasıl etkilediği sorgulanmaktadır.

\section{Kavramsal Çerçeve}

\subsection{Duygusal Emek Kavramı}

Araştırmacılar tarafından farklı şekillerde tanımlanan duygusal emek kavramı Morris ve Feldman (1996) tarafından "kişilerarası etkileşimlerde örgüt tarafından istenen duyguları gösterebilmek için gerekli olan çaba, planlama ve kontrol" olarak tanımlanmıştır. Benzer şekilde Grandey (2000) kavramı duygusal ifadeleri düzenlemek için duyguları yoğunlaştırma, bastırma veya rol yapma şeklide ifade etmiştir. Bir duygu işini ifade eden kavram (Şengül, 2009) işi gereği müşterilerle birebir iletişim halinde olan çalışanların duygusal tepkilerini örgüt için kabul edilebilir şekle sokmak veya örgüt amaçlarıyla uyumlu duygu gösterimleri yaratmak amacıyla ortaya çıkmaktadır (Köksel, 2009). Bu bağlamda duygusal emeğin temelini çalışanlardan sergilemeleri beklenen duygular ile çalışanların gerçekte hissettikleri duygular arasındaki ilişki oluşturmaktadır (Güngör, 2009: 176). Buna göre çalışanlar görevlerini ifa ederken yüzeysel rol davranışı, derin rol davranışı ya da doğal duygular şeklinde ortaya çıkan duygusal emek davranışlarından birini sergilemektedir (Ashforth \& Humphrey, 1993; Diefendorff vd., 2005). 
Örgütler, uygulayıcılar ve çalışanlar için önem arz eden duygusal emek kavramının daha iyi anlaşılabilmesi adına araştırmacılar çeşitli yaklaşımlar geliştirilmiştir. Bunların içinde en çok bilenen ve benimsenen yaklaşımlar Hochschild (1983), Ashforth ve Humprey (1993), Morris ve Fieldmen (1996), Grandey (2000)' in yaklaşımıdır. Hochschild (1983) yaklaşımında duygusal emek kavramını yüzeysel ve derinlemesine davranış şeklinde iki farklı boyutta ele almıştır. $\mathrm{Bu}$ yaklaşımda yüzeysel davranış duygunun içselleştirilmeden sadece tepki şeklinde ortaya çıkması iken, derinlemesine davranış, çalışanların duygularını gözden geçirip, üzerinde düşünerek gösterdiği samimi davranışları ifade eder (Hochschild, 1983; Grandey, 2003; Hochschild, 2003). Ashforth ve Humprey (1993) ise Hochschild (1983)'in yüzeysel ve derinlemesine davranış boyutlarına ek olarak samimi davranış boyutunu eklemiştir. Bireyin hissettiği duygular ile ifade edilen duygular ve davranışlar arasında bir uyum söz konusu olduğunda samimi davranış türü ortaya çıkmaktadır (Chu \& Murrmann, 2006: 1182). Duygusal çabada davranışın gerçek duygularla destekleniyor olması kurulan ilişkiye samimiyet kazandırmaktadır (Cho vd., 2012). Duygularını bu yolla ifade eden çalışan, karşısındaki bireye rol yapmamakta, gerçekten kendisi yardıma hazır ve olumlu duygular içinde olduğu için bu şekilde davranmaktadır (Diefendorff vd., 2005: 352). Ashforth ve Humprey (1993)'in bu yaklaşımı davranışın altında yatan duygulara değil, doğrudan davranışa odaklanması ile Halchschild (1983)'in yaklaşımından ayrılmaktadır. Morris ve Feldman'ın yaklaşımında (1996: 987) duygusal emek kavramı "kişilerarası iş süreçlerinde örgütün istediği duyguların yansıtmasında gerekli olan çaba, planlama ve kontrol" olarak tanımlamıştır. Bu yaklaşıma göre bireyin sergilemesi gereken duygu ile o anda hissettiği duygu örtüşüyor olsa bile çalışanın örgütün istediği duyguyu sergileyebilmesi için belirli bir çaba sarf etmesi gereklidir. İster yüzeysel, ister derin, ister doğal davranış gösteriyor olsun bir çalışanın iş yerinde duygularını kullanıyor olması, duygusal emek gösterdiği anlamına gelmektedir (Öz, 2007: 8). Grandey (2000: 97) ise yukarıda bahsi geçen üç yaklaşımın değişkenlerini bir araya getirerek yeni bir model oluşturmuştur. Bu yaklaşıma göre duygusal emek "örgütlerin amaçlarına hizmet edecek şekilde hem duyguların hem de ifadelerin düzenlenmesi” olarak tanımlamıştır. Duygu düzenlemesi "bireylerin göstermesi gereken davranış ve duyguların ne zaman ve nasıl yansıtılması gerektiği konusundaki süreci” ifade etmektedir (Gross, 1998: 224).

Hochschild (1983) tarafından ortaya atılan duygusal emek kavramı ile birlikte çalışanların müşteri ve çevreleri ile ilişkilerinde duygusal tepkilerinin önemine dikkat çekilmiş olup, duygusal emeğin bireyler ve örgütler üzerindeki etkilerini incelemeye yönelik birçok araştırma yapılmıştır (Ashforth \& Humphrey, 1995; Morris \& Feldman, 1996; Grandey, 2000; Rupp \& Spencer, 2006; Öz, 2007; Martinez-Inigo vd. 2007; Rupp vd., 2008; Barger, 2006; Çaldă̆ , 2010; Değirmenci, 2010; Yürür vd., 2011; Lam ve Chen, 2012; Akbıyık, 2013; Keleş, 2014; Kızanlıklı, 2014; Keleş \& Tuna, 2016). Araştırma sonuçlarına göre derin davranışın daha çok başarma, içsel tatmin, iş doyumu ve performans gibi olumlu çıktılar (Grandey vd., 2005; Brotheridge \& Grandey, 2002; Grandey, 2003; Grandey, 2000) yüzeysel davranışın ise tatminsizlik, güvensizlik, tükenmişlik gibi olumsuz sonuçlarla ilişkilendirildiği görülmektedir (Grandey vd., 2005; Brotheridge \& Grandey, 2002; Grandey, 2003; Grandey, 2000). Duygusal emeğin ilişkilendirildiği değişkenlerden birisi de çalışanın adalet algısıdır (Keleş, 2014; Rupp \& Spencer, 2006; Barger, 2009; Martinez-Inigo vd. 2007; Lam \& Chen, 2012; Keleş, 2014; Keleş \& Tuna, 2016). Bu bağlamda, araştırmamızda sağlık sektörü çalışanlarının adalet algılarının duygusal emek davranışları üzerindeki etkileri belirlenmeye çalışılmıştır. 


\section{2. Örgütsel Adalet Kavramı}

Homans'ın Sosyal Değişim Kuramı'nı öne sürmesiyle temelleri atılan örgütsel adalet kavramı Adams'ın Eşitlik Kuramı ile büyük gelişme göstermiştir (Greenberg, 1987:12). Bu anlamda kavramın temelleri Eşitlik Teorisine dayanmaktadır (İşcan \& Naktiyok, 2004; Eker, 2006; Robbins \& Judge, 2012). Teoriye göre bireyler işleri ile ilgili girdi ve çıktıları diğer bireyler ile karşılaştırarak, herhangi bir eşitsizlik algılandıklarında bu eşitsizliği ortadan kaldırmaya yönelik tepki vermektedir (İşcan \& Naktiyok, 2004; Eker, 2006; Robbins \& Judge, 2012). Örgütsel ortamlarda adalet kavramı, yöneticilerin süreç ve uygulamalarda adil ya da adaletli olma durumunu ifade etmektedir (Colquitt vd., 2001). Örgütsel adalet kavramını ilk kullananlardan birisi olan Greenberg'e göre örgütsel adalet, çalışanların örgütteki uygulama ve kararlara ilişkin adalet algılarının, kendi davranışları üzerine etkisidir (Greenberg, 2001: 211). Örgütsel adalet, örgüt içerisinde çalışanların ücretten başlayarak ödül, ceza ve kaynakların nasıl paylaşılacağından, karar mekanizmalarının nasıl çalıştığına kadar uzanan algı durumları olarak tanımlanabilir (İçerli, 2010). Alan yazında örgütsel adaletin genel olarak dağıtım adaleti, işlem adaleti ve etkileşim adaleti olarak üç boyutta incelendiği görülmektedir (Özdevecioğlu, 2003: 78).

Dağıtım adaleti, eşitlik teorisi içerisinde yer almaktadır ve eşit çabanın eşit sonuç getirmesi gerektiğine dayanır (Colquitt \& Chertkoff, 2002: 595). Dağıtımsal adalet, çalışanların elde ettiği ödül, terfi, statü, fırsat, yetki ve cezaların dağılımı konusundaki adalet algılarını ifade edilmektedir (DeConnick, 2010). İşlem adaleti, uygulama ve süreçlerde herkese temel hakların korunması ve dağıtımında eşitlikçi davranılmasını ifade eder. Bu noktada çalışanların elde ettikleri çıktıların uygunluğundan, verilen kararlara katılma oranlarına kadar her türlü örgütsel işlemin eşitliği işlem adaleti anlamına gelir (Colquitt \& Chertkoff, 2002). Leventhal (1980) örgüt içinde işlemsel adaletin varlığını etkileyebilecek altı kuraldan bahsetmiştir. Bu kriterler işlemlerin; (1) tutarlı olması, (2) yanlılıktan uzak olması, (3) doğru olması, (4) hata durumunda düzeltilebilir olması, (5) herkesi dikkate alması, (6) ahlaki standartlara uygun olmasıdır. Bu anlamda bir örgütte işlem adaletinin varlığından bahsedebilmek için karar alma sürecinde doğru bilgilerin kullanması, kararlardan etkilenebilecek kişi ve grupların karar alma süreçlerinde temsil edilmesi, işlem ve uygulamalar sırasında önyargıdan uzak, etik değerlere uygun, kişiden kişiye değişmeyen prosedür ve uygulamaların varlığı ile gerektiğinde alınan kararlara itiraz edebilme ve verilen kararları etkiyebilmeye ilişkin hakların varlığ 1 gerekmektedir. Etkileşim adaleti ise örgüt içindeki bireylerin birbirlerine karşı davranışlarında algılanan dürüstlük düzeyini ifade edilmektedir (Yazıcıoğlu \&Topaloğlu, 2009: 5). Adil etkileşim işlem ve süreçlere ilişkin her türlü kişilerarası iletişimin adil olarak tanımlanmasını ifade eder (Moorman, 1991).

Son yıllarda birçok araştırmaya konu olan örgütsel adalet algısı çalışanların tutum ve davranışlarını etkileyebilme gücü nedeniyle örgütler için kritik bir öneme sahiptir. Bu anlamda adalet algısı yüksek bireylerin örgütsel amaç ve hedeflere ulaşma yolunda olumlu ve istendik davranışlar sergilediği, adalet algısı düşük çalışanların ise öfke, kin, utanç ve suçluluk gibi yıkıcı duygular geliştirerek (Hess, 2003) örgütsel amaçlara ulaşmadaki katkılarını en aza indirgedikleri söylenebilir. Yine bu bireylerde devamsızlık, işe geç gelme, gelmeme, işten ayrılma niyeti, sabotaj gibi verimlilik karşıtı örgüt içi saldırgan davranışlar görülmesi daha olasıdır (Organ, 1988: 88; Skarlicki \& Folger, 1997; Aquino vd., 1999; Özdevecioğlu, 2003; Jones, 2009). 


\section{Yöntem}

\subsection{Evren ve Örneklem}

Dünyanın en karmaşık ve değişken sektörü olarak da bilinen sağlık sektörü doğrudan ve dolaylı olmak üzere farklı meslek gruplarından çalışanları bir araya getiren ve toplumun her kesimi için hizmet üreten emek yoğun bir işkoludur. Sağlık sektöründe çalışan bireylerin örgütsel adalet algılarının duygusal emek davranışları üzerindeki etkisini belirlemek amacıyla yapılan araştırmanın evrenini, Nevşehir il merkezinde faaliyet gösteren kamu hastanesine bağlı 112 acil servis çalışanları oluşturmaktadır. Araştırmanın yapıldığı dönemde kamu hastanesine bağlı 162 çalışan bulunmaktaydı. Araştırma için evrenden örneklem seçilmeyerek evrenin tamamına ulaşılması hedeflenmiştir. Dağıtılan 162 anketin hepsi geri dönmüş ve değerlendirmeye alınmıştır.

\subsection{Araştırma Hipotezleri ve Modeli}

$\mathrm{Bu}$ araştırmada sağlık ve bakım hizmetlerinin anahtarı olarak kabul edilen çalışanların örgütsel adalet algılarının, çalışanların işlerini yaparken hissettikleri duygular ve bu duyguların davranışa dönüşmesindeki etkisi çok boyutlu olarak açıklanmaya çalışılmıştır. Bu anlamda araştırmanın hipotezleri şu şekildedir:

$\mathbf{H}_{1}$ : Örgütsel adalet algısının alt boyutu olan dağıtım adaleti duygusal emeğin alt boyutları olan yüzeysel rol yapma, derinden rol yapma, doğal duygular üzerinde etkilidir.

$\mathbf{H}_{2}$ : Örgütsel adalet algısının alt boyutu olan işlem adaleti duygusal emeğin alt boyutları olan yüzeysel rol yapma, derinden rol yapma, doğal duygular üzerinde etkilidir.

$\mathbf{H}_{3}$ : Örgütsel adalet algısının alt boyutu olan etkileşim adaleti duygusal emeğin alt boyutları olan yüzeysel rol yapma, derinden rol yapma, doğal duygular üzerinde etkilidir.

\subsection{Veri Toplama Aracı}

Araştırma amaçları doğrultusunda kullanılan veriler iki farklı anket yardımı ile toplanmıştır. Örgütsel adalet algısının ölçülmesi için Colquitt (2001) tarafından geliştirilen “Örgütsel Adalet Ölçeğì", duygusal emek davranışlarının ölçümüi için Diefendorff vd. (2005) tarafından Kruml ve Geddes (2000) ile Grandey (2003)'in ölçeklerinden uyarlanarak geliştirilen ve Basım ve Beğenirbaş (2012) tarafından Türkçe'ye uyarlanan "Duygusal Emek Ölçeği” kullanılmıştır. Araştırmada kullanılan örgütsel adalet algısı ve duygusal emek ölçeklerinin yapısal geçerliliğini belirlemek amacıyla açımlayıcı faktör analizi (AFA) uygulanmıştır. Analiz sonucunda Kaiser-Meyer-Olkin Testinin (KMO) değeri örgütsel adalet ölçeği için .89, duygusal emek ölçeği için .88 olarak tespit edilmiştir. Bu değer örneklem büyüklügüunün faktör analizi için uygun (Çokluk vd., 2012) olduğunu göstermektedir. Bartlett küresellik testi sonuçları incelendiğinde ise örgütsel adalet ve duygusal emek ölçeği için sırasıyla hesaplanan $\left(\mathrm{X}_{(78)}^{2}=5053,166 ; \mathrm{p}<.01 ; \mathrm{X}_{(91)}^{2}=2578.547 ; \mathrm{p}<.01\right)$ ki-kare değerinin anlaml olduğu bulgulanmıştır. Bu sonuçlar ışığında veri setinin faktör analizine uygun olduğu ve çok değişkenli normal dağılım gösterdiği söylenebilir (Çokluk vd., 2010: 208). 


\subsection{1. Örgütsel Adalet Algısı Ölçeği}

Araştırma amaçlarına uygun olarak örgütsel adalet algısını belirleyebilmek için Colquitt (2001) tarafından geliştirilen ve Özmen (2007) tarafından Türkçe'ye uyarlanan örgütsel adalet ölçeği kullanılmıştır. 5'li likert tipindeki ölçeğin seçenekleri "Hiç Katılmıyorum" dan "Kesinlikle Katılıyorum” arasında değişmektedir.

Örgütsel adalet ölçeğine ilişkin açımlayıcı faktör analizi sonucunda 13 madde için özdeğeri 1'in üzerinde üç boyutun toplam varsyansı açılama oranı \%93.996'dur. Buna göre ölçeğin ilk dört maddesi işlem adaleti, 5'ten 9'a kadar olan maddeler etkileşim adaleti ve 10'dan 13'e kadar olan maddeler ise dağıtım adaleti ile ilgilidir. Yapılan açımlayıcı faktör analizi sonuçlarına göre orijinal ölçeğin üç boyutlu yapısı doğrulanmış ve ölçeğin yapı geçerliliğine sahip olduğu görülmüştür.

Yine kullanılan ölçek yapıları ve maddelerle olan ilişkilerini belirleyebilmek için Yapısal Eşitlik Modeli (YEM) kapsamında birinci düzey doğrulayıcı faktör modeli oluşturulmuştur. Örgütsel adalet algısını ölçmeye yönelik 13 ifade 3 boyutta modellenmiştir. Yapılan doğrulayıcı faktör analizinden elde edilen modelin uyum indeksleri incelenmiş ve minimum ki-kare değerinin $\left(\chi^{2}=477,909 \mathrm{df}=123, p=0.00\right)$ anlamlı olduğu görülmüsştür. Uyum indeksi değerleri ise $\mathrm{RMSEA}=0.06, \mathrm{GFI}=0.92, \mathrm{CFI}=0.90, \mathrm{AGFI}=0.91$ olarak bulunmuştur. Araştırmada kullanılan örgütsel adalet algısı ölçeğinin, maddeleri ile ilişkisinin belirlenmesi amacıyla yapılan birinci düzey doğrulayıcı faktör analizinden elde edilen sonuçlar üç faktörlü modelin kabul edilebilir olduğunu göstermektedir. Örgütsel adalet ölçeğine ilişkin hesaplanan Cronbach Alpha iç güvenirlik katsayısı ise $\alpha=.92$ olarak bulunmuştur.

\subsubsection{Duygusal Emek Ölçeği}

Katılımcıların duygusal emek davranışlarını belirleyebilmek için Diefendorff vd. (2005) tarafından, Kruml ve Geddes (2000) ile Grandey (2003)'in ölçeklerinden uyarlanarak geliştirilen ve Basım ve Beğenirbaş (2012) tarafından Türkçe' ye uyarlanan "Duygusal Emek Ölçeği" kullanılmıştır. 14 maddeden oluşan ölçek yüzeysel rol yapma, derinden rol yapma ve doğal duygular alt boyutlarından oluşmaktadır. 5'li likert tipindeki ölçekte " Hiçbir zaman” ile "Her zaman" ifadeleri yer almaktadır.

Yine duygusal emek ölçeği açımlayıcı faktör analizi sonucunda 14 madde için özdeğeri 1 'in üzerinde üç boyutun toplam varyansı açıklama oranı \% 79.517'dir. Buna göre ölçeğin ilk altı maddesi yüzeysel rol davranışı, 7-10'a kadar derin rol davranışı ve 11'den 14'e kadar olan maddeler ise doğal duygular ile ilgilidir. Yapılan açımlayıcı faktör analizi sonuçlarına göre orijinal ölçeğin üç boyutlu yapısı doğrulanmış ve ölçeğin yapı geçerliliğine sahip olduğu görülmüsştür. Yine duygusal emek ölçeği için yapılan doğrulayıcı faktör analizinden elde edilen modelin uyum indeksleri incelenmiş ve minimum ki-kare değerinin $\left(\chi^{2}=469,827 \mathrm{df}=143\right.$, $p=0.00$ ) anlamlı olduğu görülmüştür. Uyum indeksi değerleri ise RMSEA $=0.07, \mathrm{GFI}=0.90$, CFI=0.91, AGFI $=0.90$ olarak bulunmuştur. Araştırmada kullanılan duygusal emek ölçeğinin maddeleri ile ilişkisinin belirlenmesi amacıyla yapılan birinci düzey doğrulayıcı faktör analizinden elde edilen sonuçlar üç faktörlü modelin kabul edilebilir olduğunu göstermektedir. Duygusal emek ölçeğine ilişkin hesaplanan Cronbach Alpha iç güvenirlik katsayısı ise $\alpha=$ .91 'dir. 


\section{Verilerin Analizi}

$\mathrm{Bu}$ araştırmada örgütsel adalet algısı ve duygusal emek arasındaki ilişkileri yansıtan bir model oluşturulmaya çalışılmıştır. Literatür 1şı̆̆ında örgütsel adalet algısının "dağıtım adaleti”, "işlem adaleti" ve "etkileşim adaleti" olmak üzere üç, duygusal emeğin de yine "derinden rol davranışı", "yüzeysel rol davranışı" ve "doğal duygular" olmak üzere üç boyutta incelendiği söylenebilir.

Araştırmanın temel amaçlarına ulaşmak için yapılacak istatistiksel analizler öncesi tüm değişkenler normal dağılım açısından incelenmiştir. Değişkenler arasındaki çok değişkenli normallik için yürütülen istatistiklere göre basıklık katsayıları -.120 ile .602 ve çarpıklık katsayıları ise -,607 ile .151 arasında değişmektedir. Bu sonuca göre çok değişkenli normallik varsayımlarının sağlandığı yorumu yapılabilir. Bu değerler 1şı̆̆ında modelleme çalışması sırasında 0.05 anlamlılık düzeyinde en çok olabilirlik (Maximum Likelihood) yaklaşımı kullanılmıştır.

\subsection{Araştırma Bulguları}

Araştırma kapsamında elde edilen veriler uygun istatistiki programlardan yararlanarak analiz edilmiştir. Bu anlamda ilk aşamada araştırmaya katılan 112 acil servis istasyonları çalışanlarının demografik özelliklerine ilişkin bulgular incelenmiştir. Buna göre araştırmaya katılan çalışanların \% 52.4'ü erkek; \%39.6'sı 26-30 yaş aralığında; \%65.2'si evli; \%50'si 6-10 arasında deneyime sahip;\%62.8'i ise acil tıp teknisyenidir.

Araştırmanın sonraki bölümünde ise örgütsel adalet ve duygusal emek kavramına ilişkin elde edilen verilerin ortalamaları, standart sapmaları ve aralarındaki korelasyonlara bakılmıştır. $\mathrm{Bu}$ analize ilişkin veriler Tablo 1'de yer almaktadır.

Tablo 1: Örgütsel Adalet Algısı ve Duygusal Emek Arasındaki Korelasyon Analizi Sonuçları

\begin{tabular}{|c|c|c|c|c|c|c|c|c|c|c|}
\hline & Ort. & S.S. & ÖAA & DEÖ & İŞL & ETK & DAĞ & YÜZ & DER & DOĞ \\
\hline ÖAA & 2.61 & 2.61 & 1 & & & & & & & \\
\hline DEÖ & 3,28 & 1.65 & $.369 * *$ & 1 & & & & & & \\
\hline İŞL & 4.18 & .79 & $.703 * *$ & $.243 * *$ & 1 & & & & & \\
\hline ETK & 3.75 & 1,07 & $.953 * *$ & $.345^{* *}$ & $.479 * *$ & 1 & & & & \\
\hline DAĞ & 3,72 & 1,07 & $.956 * *$ & $.371 * *$ & $.489 * *$ & $.959 * *$ & 1 & & & \\
\hline YÜZ & 2.98 & .62 & $.291 * *$ & $.860 * *$ & $.225^{* *}$ & $.248 * *$ & $.292 * *$ & 1 & & \\
\hline DER & 3.74 & .68 & $.394 * *$ & $.913 * *$ & $.283 * *$ & $.360 * *$ & $.389 * *$ & $.668 * *$ & 1 & \\
\hline DOĞ & 3.28 & .57 & $.281 * *$ & $.872 * *$ & .121 & $.300 * *$ & $.293^{* *}$ & $.607 * *$ & $.724 * *$ & 1 \\
\hline
\end{tabular}

ÖA: Örgütsel Adalet Algısı; DEÖ: Duygusal Emek Ölçeği; İŞL: İşlem Adaleti; ETK: Etkileşim Adaleti; DAĞ: Dağıtım Adaleti; YÜZ: Yüzeysel Rol Davranışı; DER: Derin Rol Davranışı: DOĞ: Doğal Rol Davranışı ** İlişkinin \%1 düzeyinde anlamlı olduğunu göstermektedir $(\mathrm{p}<.01)$.

Tablo 1 incelendiğinde örgütsel adalet algısı ve örgütsel adaletin alt boyutları ile duygusal emek ve duygusal emeğin alt boyutlarına ilişkin katsayıların istatistiki olarak anlamlı $(\mathrm{p}<.01)$ 
olduğu görülmektedir. Buna göre örgütsel adalet algısı ile duygusal emek ( $r=.36$ ve p=.00) arasında pozitif yönlü düşük kuvvette bir korelasyon tespit edilmiştir. Bu anlamda çalışmada ele alının örgütsel adalet ile duygusal emek arasındaki ilişkinin belirlenmesi önemli görülmektedir. Tablo 1'e göre örgütsel adalet algısı ile duygusal emek ( $r=.36$ ve $\mathrm{p}=.00)$; duygusal emeğin alt boyutları olan yüzeysel rol davranışı $(\mathrm{r}=.29$ ve $\mathrm{p}=.00)$; derinden rol davranışı $(\mathrm{r}=.39$ ve $\mathrm{p}=.00)$ ve doğal rol davranışı ( $\mathrm{r}=.28$ ve $\mathrm{p}=.00)$ arasında pozitif yönlü düşük denilebilecek kuvvette bir korelasyon tespit edilmiştir.

Örgütsel adalet ölçeğinin alt boyutu olan işlem adaleti ile duygusal emek ölçeği ( $r=.24$ ve $\mathrm{p}=.00)$; duygusal emek ölçeğinin alt boyutları olan yüzeysel rol davranışı ( $\mathrm{r}=.22$ ve $\mathrm{p}=$ $.00)$ ve derin rol davranışı $(\mathrm{r}=.28$ ve $\mathrm{p}=.00)$ arasında pozitif yönlü düşük kuvvette anlamlı bir korelasyon tespit edilmişken doğal rol davranışı $(\mathrm{r}=.12$ ve $\mathrm{p}>.01)$ ile düşük kuvvette anlamsız bir korelasyon tespit edilmiştir.

Örgütsel adalet ölçeğinin alt boyutu olan etkileşim adaleti ile duygusal emek ölçeği $(\mathrm{r}=.34$ ve $\mathrm{p}=.00)$; duygusal emek ölçeğinin alt boyutları olan yüzeysel rol davranışı $(\mathrm{r}=.24$ ve $\mathrm{p}=.00)$ ve derin rol davranışı $(\mathrm{r}=.36 \mathrm{ve} \mathrm{p}=.00)$ ve son olarak doğal rol davranışı $(\mathrm{r}=.30$ ve $\mathrm{p}=.01)$ ile düşük kuvvette bir korelasyon tespit edilmiştir.

Örgütsel adalet ölçeğinin alt boyutu olan dağıtım adaleti ile duygusal emek ölçeği ( $r=.37$ ve $\mathrm{p}=.00)$; duygusal emek ölçeğinin alt boyutları olan yüzeysel rol davranışı $(\mathrm{r}=.29$ ve $\mathrm{p}=.00)$ ve derin rol davranışı $(\mathrm{r}=.38$ ve $\mathrm{p}=.00)$ ve son olarak doğal rol davranışı $(\mathrm{r}=.29$ ve $\mathrm{p}=.01)$ ile düşük kuvvette bir korelasyon tespit edilmiştir.

\subsection{Regresyon Analizine İlişkin Bulgular}

Araştırmanın bu bölümünde, değişkenlerin birbiri üzerindeki etkilerinin ortaya konulması amacıyla çoklu doğrusal regresyon analizi kullanılmıştır. Birden çok açıklayıcı değişkenli modeller çoklu regresyon modeli olarak adlandırılmaktadır (Kalaycı, 2010: 260). Regresyon analizi, bir bağımlı değişken ile bir veya daha fazla bağımsız değişken arasındaki neden sonuç ilişkisini matematiksel bir modelle açıklayan yöntem olarak tanımlanmaktadır (Özdamar, 2011: 524). Bu anlamda örgütsel adalet algısının duygusal emek üzerindeki etkisini belirlemek üzere oluşturulan model özeti Tablo 2'de verilmiştir.

Tablo 2: Örgütsel Adalet Algılarının Duygusal Emek Davranışı Üzerine Etkisi

\begin{tabular}{lcccccccc}
\hline Değişkenler & \multicolumn{2}{c}{ Model Özeti } & \multicolumn{2}{c}{ Anova } & \multicolumn{3}{c}{ Katsayılar } \\
\hline Bağımsız Değişken & $\mathbf{R}^{\mathbf{2}}$ & $\mathbf{R}$ & $\mathbf{F}$ & $\mathbf{p}$ & $\beta$ & $\mathbf{t}$ & $\mathbf{p}$ \\
\hline Örgütsel adalet & .136 & .369 & $25,167$. & .000 & .369 & 5.017 & $.000^{*}$ \\
\hline
\end{tabular}

* $\mathrm{p}<0.05$

Duygusal Emek Davranı̧̧ı

Tablo 2'de yer alan basit doğrusal regresyon analizindeki $\mathrm{R}^{2}$ determinasyon katsayısı değerine göre yüzeysel rol davranışında meydana gelen değişiklerin \%13.6'sı $\left(\mathrm{R}^{2}=.136\right)$ bağımsız değişkenler olan örgütsel adalet algısı tarafından açıklanmaktadır. Buna göre örgütsel adalet algısı ile duygusal emek davranışı arasında anlamlı ve pozitif yönlü bir etkileşim bulunmuştur $(\beta=.369 ; \mathrm{t}=5.017 ; \mathrm{p}=.000)$. 
Tablo 3: Örgütsel Adalet Algılarının Yüzeysel Rol Davranışı Üzerine Etkisi

\begin{tabular}{|c|c|c|c|c|c|c|c|}
\hline \multirow{2}{*}{$\begin{array}{l}\text { Değişkenler } \\
\text { Bağımsız Değişken }\end{array}$} & \multicolumn{2}{|c|}{ Model Özeti } & \multicolumn{2}{|c|}{ Anova } & \multicolumn{3}{|c|}{ Katsayılar } \\
\hline & $\mathbf{R}^{2}$ & $\mathbf{R}$ & $\mathbf{F}$ & $\mathbf{p}$ & $\beta$ & $\mathbf{t}$ & $\mathbf{p}$ \\
\hline İşlem Adaleti & \multirow{3}{*}{.090} & \multirow{3}{*}{.328} & \multirow{3}{*}{6.334} & \multirow{3}{*}{.000} & .113 & 1.313 & .191 \\
\hline Etkileşim Adaleti & & & & & -.407 & -1.535 & .127 \\
\hline Dağıtım Adaleti & & & & & .627 & 2.348 & $.020 *$ \\
\hline
\end{tabular}

*p $<0.05$

Not: Bağımlı değişken: Yüzeysel Rol Davranışı

Tablo 3'te yer alan çoklu doğrusal regresyon analizindeki $\mathrm{R}^{2}$ determinasyon katsayısı değerine göre yüzeysel rol davranışında meydana gelen değişiklerin \%9'u ( $\left.\mathrm{R}^{2}=.090\right)$ bağımsız değişkenler olan işlem adaleti, etkileşim adaleti ve dağıtım adaleti boyutları tarafından açıklanmaktadır. $\beta$ değerine dayanarak yüzeysel rol davranışını etkileyen örgütsel adalet boyutlarının olduğu görülmektedir. Buna göre dağıtım adaleti boyutu yüzeysel rol davranışını etkileyen en önemli bağımsız değişkendir. Bu iki değişken arasında anlamlı ve pozitif yönlü bir etkileşim bulunmuştur $(\beta=.627 ; \mathrm{t}=2.348 ; \mathrm{p}=.020)$. İşlem adaleti ve etkileşim adaleti boyutları ile yüzeysel rol davranışı boyutu arasında istatistiksel olarak anlamlı bir etkileşim bulunmamaktır $(\beta=.113, \mathrm{t}=1.313, \mathrm{p}=.191 ; \beta=-.407 ; \mathrm{t}=-1.535 ; \mathrm{p}=.127)$.

Tablo 4: Örgütsel Adalet Algılarının Derin Rol Davranışı Üzerine Etkisi

\begin{tabular}{|c|c|c|c|c|c|c|c|}
\hline \multirow{2}{*}{$\frac{\text { Değişkenler }}{\text { Bağımsız Değişken }}$} & \multicolumn{2}{|c|}{ Model Özeti } & \multicolumn{2}{|c|}{ Anova } & \multicolumn{3}{|c|}{ Katsayılar } \\
\hline & $\mathbf{R}^{2}$ & $\mathbf{R}$ & $\mathbf{F}$ & $\mathbf{p}$ & $\beta$ & $\mathbf{t}$ & $\mathbf{P}$ \\
\hline İşlem Adaleti & \multirow{3}{*}{.165} & \multirow{3}{*}{.407} & \multirow{3}{*}{10.430} & \multirow{3}{*}{.000} & .125 & 1.493 & .138 \\
\hline Etkileşim Adaleti & & & & & -..183 & -.713 & .477 \\
\hline Dağıtım Adaleti & & & & & .503 & 2.112 & $.050 *$ \\
\hline
\end{tabular}

${ }^{*} \mathrm{p}<0.05$

Not: Bağımlı değişken: Derin Rol Davranışı

Tablo 4 göz önünde bulundurulduğunda çoklu doğrusal regresyon analizi denklemindeki $\mathrm{R}^{2}$ determinasyon katsayısı değerine göre derin rol davranışında meydana gelen değişiklerin \%16.5'i $\left(\mathrm{R}^{2}=.165\right)$ bağımsız değişkenleri olan işlem adaleti, etkileşim adaleti ve dağıtım adaleti boyutları tarafından açıklanmaktadır. Yine $\beta$ değerine dayanarak derin rol davranışını etkileyen örgütsel adalet boyutlarının olduğu görülmektedir. Dağıtım adaleti boyutu derin rol davranışını etkileyen en önemli bağımsız değişkendir. Bu iki değişken arasında anlamlı pozitif yönlü bir etkileşim bulunmuştur $(\beta=.503 ; \mathrm{t}=2.112 \mathrm{p}=.050)$. Ancak işlem adaleti ve etkileşim adaleti boyutları ile derin rol davranışı boyutu arasında istatistiksel olarak anlamlı bir etkileşim bulunmamaktır $(\beta=.125, \mathrm{t}=1.493, \mathrm{p}=.138 ; \beta=-.183 ; \mathrm{t}=-.713 ; \mathrm{p}=.477)$.

Tablo 5'teki çoklu doğrusal regresyon analizi denklemindeki $\mathrm{R}^{2}$ determinasyon katsayısı değerine göre doğal rol davranışında meydana gelen değişiklerin \%9.1'i $\left(\mathrm{R}^{2}=.091\right)$ bağımsız değişkenler olan işlem adaleti, etkileşim adaleti ve dağıtım adaleti boyutları tarafından açıklanmaktadır. Yine $\beta$ değerine dayanarak doğal rol davranışını etkileyen örgütsel adalet boyutlarının olduğu görülmektedir. Etkileşim adaleti boyutu doğal rol davranışını etkileyen en 
Tablo 5: Örgütsel Adalet Algılarının Doğal Rol Davranışı Üzerine Etkisi

\begin{tabular}{|c|c|c|c|c|c|c|c|}
\hline \multirow{2}{*}{$\begin{array}{l}\text { Değişkenler } \\
\text { Bağımsız Değişken }\end{array}$} & \multicolumn{2}{|c|}{ Model Özeti } & \multicolumn{2}{|c|}{ Anova } & \multicolumn{3}{|c|}{ Katsayılar } \\
\hline & $\mathbf{R}^{2}$ & $\mathbf{R}$ & $\mathbf{F}$ & $\mathbf{p}$ & $\beta$ & $\mathbf{t}$ & $\mathbf{P}$ \\
\hline İşlem Adaleti & \multirow{3}{*}{.091} & \multirow{3}{*}{.302} & \multirow{3}{*}{5.297} & \multirow{3}{*}{.002} & -.033 & -.383 & .702 \\
\hline Etkileşim Adaleti & & & & & .242 & .905 & .367 \\
\hline Dağıtım Adaleti & & & & & & .287 & .775 \\
\hline
\end{tabular}

$* \mathrm{p}<0.05$

Not: Bağımlı değişken: Doğal Rol Davranışı

önemli bağımsız değişkendir ( $\beta=.242)$. Ancak örgütsel adalet algısının hiçbir alt boyutu (işlemetkileşim-dağıtım adaleti) ile doğal rol davranışı boyutu arasında istatistiksel olarak anlamlı bir etkileşim bulunmamaktır $(\beta=-.033, \mathrm{t}=-.383, \mathrm{p}=.702 ; \beta=.242 ; \mathrm{t}=.905 ; \mathrm{p}=.367 ; \beta=.077, \mathrm{t}=.287$, $\mathrm{p}=.775)$.

Araştırma kapsamında modele katkısı en fazla olan değişkenin belirlenebilmesi adını aşamalı regresyon tekniği kullanılmıştır. Aşamalı (stepwise) regresyon analizinde duygusal emek ile anlamlı ilişkiler gösteren örgütsel adalet algısının alt boyutları olan işlem, etkileşim ve dağıtım adaleti alt ölçekleri regresyon analizine tabi tutulmuştur.

Tablo 6: Duygusal Emeği Yordayan Değişkenlere İlişkin Aşamalı Regresyon Analizi Sonuçları

\begin{tabular}{llccccc}
\hline Bağımlı Değişken & Bağımsız Değişken & $\mathbf{R}$ & $\mathbf{R}^{\mathbf{2}}$ & $\mathbf{S . S}$ & $\mathbf{F}$ & $\boldsymbol{\beta}$ \\
\hline $\begin{array}{l}\text { Yüzeysel Rol } \\
\text { Davranışı }\end{array}$ & Dağıtım Adaleti & .292 & .085 & .59 & 14.89 & .292 \\
\hline Derin Rol Davranışı & Dağıtım Adaleti & .389 & .151 & .62 & 28.51 & .246 \\
\hline Doğal Rol Davranışı & Etkileşim Adaleti & .300 & .090 & .55 & 15.86 & .160 \\
\hline
\end{tabular}

Tablo 6 incelendiğinde duygusal emeğin alt boyutu olan yüzeysel rol davranışını ve derin rol davranışını en çok yordayan değişkenin sırasıyla \%0.85 ve \%15'lik varyansı açıklama yüzdesi ile dağıtım adaleti olduğu, doğal rol davranışı alt boyutunu en çok yordayan değişkenin ise \%0.90’lık varyansı açıklama yüzdesi ile etkileşim adaleti olduğu görülmektedir.

\section{Sonuç ve Öneriler}

Sağlık sektörü toplumun bütünü için sağlık hizmeti üreten emek yoğun bir hizmet dalıdır. Yüksek düzeyde işbirliği, uyum ve güven gerektiren bu sektörde çalışanların örgütsel adalet algılarının duygusal emek davranışlarını nasıl ve ne boyutta etkilediğinin belirlenmesi araştırmanın amacını oluşturmaktadır. Yine örgütsel adalet algısının çalışanların duygusal tepkilerini kabul edilebilir bir şekilde yansıtmak adına harcadıkları çaba, planlama ve kontrol yeteneklerini etkilediği düşüncesi araştırmanın çıkış noktasını oluşturmaktadır.

Nevşehir il merkezinde faaliyet gösteren kamu hastanesine bağlı 112 acil servis istasyonları çalışanları üzerine yapılan bu araştırmada 162 sağlık personelinin örgütsel adalet 
algıları ile duygusal emek davranışları arasındaki ilişkinin boyutu ve etkisi incelenmiştir. Araştırma kapsamında kullanılan ölçekler ve ölçeklerin maddeleri ile ilişkilerini belirlemek amacıyla açımlayıcı (AFA) ve birinci düzey doğrulayıcı faktör analizi (DFA) yapılmıştır. Analiz sonucunda elde edilen faktör yapıları ve uyum indeksleri ölçme araçlarının kabul edilebilir uyum iyiliğine sahip olduğunu göstermiştir.

Emek ve duygusal sermayenin çok büyük önem arz ettiği sağlık sektöründe yapılan bu araştırmada örgütsel adaletin alt boyutlarına ilişkin çalışan görüşleri incelendiğinde işlem adaletine ilişkin katılımın etkileşim ve dağıtım adaletine ilişkin katılımdan daha yüksek olduğu görülmektedir. Yine duygusal emeğin alt boyutlarına ilişkin çalışan görüşlerinin birbirinden farklılık arz ettiği söylenebilir. Bu anlamda en düşük ortalama değer yüzeysel rol yapma, en yüksek ortalama değerin ise derinden rol yapma davranışına ait olduğu görülmektedir.

Örgütsel adalet ve duygusal emek arasındaki ilişkileri belirlemek adına yapılan korelasyon analizi sonuçlarına göre örgütsel adalet algısı ile duygusal emek arasında pozitif yönlü düşük kuvvette bir korelasyon tespit edilmiştir. Araştırmanın bu sonucu ülkemizde Keleş (2014) tarafından turizm çalışanları üzerine yapılan araştırma ile paralellik göstermektedir (Keleş, 2014). Alt boyutlara ilişkin değerlendirmede ise doğal rol davranışı ile işlem adaleti arasında anlamlı bir ilişki tespit edilemezken, etkileşim ve dağıtım adaleti alt boyutları ile doğal rol davranışı arasında anlamlı ve birbirine yakın bir ilişki bulunmuştur. Yine derin rol davranışı ve yüzeysel rol davranışının dağıtım adaleti ile ilişkisinde yüksek ortalamaya sahip olduğu, bunu etkileşim ve işlem adaletinin izlediği söylenebilir.

Araştırma amaçları doğrultusunda yapılan basit doğrusal regresyon analizinde örgütsel adalet algısı ile duygusal emek davranışı arasında anlamlı ve pozitif yönlü bir etkileşim olduğu sonucuna ulaşılmıştır. Buna göre çalışanların adalet algıları arttıkça duygusal emek davranışları da artmaktadır. Araştırmanın bu sonucu çeşitli araştırmalar tarafından desteklenmektedir (Rupp \& Spencer, 2006; Barger, 2009; Martinez-Inigo vd. 2007; Lam \& Chen, 2012; Keleş, 2014; Keleş \& Tuna, 2016). Yine sağlık çalışanlarının etkileşim, dağıtım ve işlem adaletine ilişkin algılarının derin, yüzeysel ve doğal rol davranışları üzerindeki etkisini tespit etmek amacıyla çoklu doğrusal regresyon analizi yapılmıştır. Analiz sonuçlarına göre dağıtım adaleti yüzeysel rol davranışı ve derin rol davranışı üzerinde anlamlı etkiye sahipken; işlem adaleti ve etkileşim adaletinin yüzeysel rol davranışı ve derin rol davranışı üzerinde anlamlı bir etkiye sahip olmadığı görülmüştür. Yine örgütsel adaletin hiç bir boyutunun doğal rol davranışı üzerinde anlamlı bir etkiye sahip olmadı̆̆

Araştırma sonucunda etkileşim adaletinin yüzeysel ve derin rol davranışı üzerindeki etkisi negatifken, doğal rol davranışı üzerindeki etkisinin pozitif olması ilginç bir sonuç olarak değerlendirilebilir. Örgütsel uygulamaların insani yanını ifade eden etkileşim adaleti, prosedürleri uygulamakla sorumlu kişilerin çalışanlara gösterdikleri tutum ve davranışlarla ilgilidir. Yüzeysel rol davranışını benimseyen çalışanlar kendi gerçek duygularından farklı olarak yönetici ve işin gerekleri çerçevesinde kendilerinden beklenen duyguları göstermektedir. $\mathrm{Bu}$ yüzden etkileşim adaleti algısı arttıkça yüzeysel rol davranışının azalması normal olarak kabul edilebilir. Yönetici ve uygulayıcıların çalışanlarla ilişkilerini yürütme tarzı saygı, sevgi ve güven temeline dayanıyorsa çalışanların duygularını ifade etmede yüzeysel rol davranışının basit teknikleri olarak kabul edilen ses tonu, mimik ve jestlerde değişikliğe giderek özümsemeden 
sadece tepki şeklindeki davranışları azalacaktır. Yine araştırma sonuçlarına göre etkileşim adalet algısı arttıkça yüzeysel rol davranışı ile zıt bir kutup gibi çalışan ancak yine çalışanların gerçekte hissettikleri ile sergiledikleri davranışlar arasında büyük farklılığı ifade eden derin rol davranışı azalmaktadır. Çünkü derin rol davranışı gösteren çalışanlar kendilerinden beklenen davranışları sergileyebilmek adına yalnızca ses tonu, mimik ve jestlerini değiştirmemektedir. Çalışanlar kendilerinden beklenen davranışları sergileyebilmek adına hayal güçlerini kullanıp, geçmiş anıları ile bağlantı kurarak duruma uygun ifadeyi yansıtmaktadır. Yine bu rol davranışında da kişinin gerçekte hissettiği duygular ile hissetmesi beklenilen duygular arasındaki fark rahatsız edicidir. Ancak doğal rol davranışı gösteren çalışanların hissettikleri duygular ile onlardan gösterilmesi beklenen davranışlar arasında uyum söz konusudur. Etkileşim adaletinin varlığı yönetici ve kurumun çalışanlarını önemsediğinin bir göstergesi olarak kabul edilebilir. Örgüt içindeki kararlara katılım derecesinden alınan kararların çalışanlara aktarılma tarzına, örgütteki çeşitli süreç ve işlerin adaletli olup olmadığına ilişkin inançtan, çalışanların maruz kaldıkları kişiler arası muameleye kadar birçok örgütsel uygulama ve sürecin sevgi, saygı, nezaket kurallarına dayandırılmasını ifade eder. Etkileşim adaleti sayesinde amirlerin çalışanı desteklemesi, geliştirmesi, güven ve değer verdiklerini göstermelerinin çalışanlarda iç kaynaklı bir güdülenme yaratarak doğal davranışları güçlendirdiği düşünülebilir.

Yine araştırma kapsamında duygusal emeğin her bir alt boyutu ele alınarak, adalet algısının alt boyutlarından en çok hangisinin, bu boyutları açıkladığını belirlemek adına aşamalı (stepwise) regresyon analizi uygulanmıştır. Analiz sonuçlarına göre duygusal emeğin alt boyutu olan yüzeysel rol davranışı ve derin rol davranışını en çok yordayan değişkenin dağıtım adaleti, doğal rol davranışı alt boyutunu en çok yordayan değişkenin ise etkileşim adaleti olduğu görülmektedir. Çalışanların örgüt içinde ödül, terfi, ücret, prim, kaynak, bilgi, fırsat vb. tüm çıktıların dürüst bir şekilde paylaşıldığına ilişkin algılarını ifade eden dağıtım adaletinin hem yüzeysel rol davranışı hem de derin rol davranışı üzerinde etkiye sahip olması dikkat çekici bir sonuçtur. Bu sonuç çalışanların göstermesi gereken duygu eksenli davranışları şekillendiren en önemli algının dağıtım adaleti olduğu şeklinde yorumlanabilir. Yapılan literatür taramasında yüzeysel rol davranışı ile derin rol davranışının özel çaba ve emek gerektirdiği, bunun içinde adalet algısına ihtiyaç duyulduğu belirtilmektedir (Brotheridge \& Grandey, 2002; Brotherige \& Lee, 2002). Yine Glomb, Kammeyer-Mueller ve Rotundo’da (2004) araştırmasında çalışanların kazanım miktarından ziyade adil dağıtımı dikkate alarak duygu gösteriminde bulunduklarını belirtmektedir.

Yine bu analiz sonuçlarına göre örgütsel adaletin doğal rol davranışı üzerinde herhangi bir etkiye sahip olmadığı ancak çalışanlarda esas motivasyon yaratan adalet boyutunun etkileşim adaleti olduğu söylenebilir. Çalışanların her zaman duygusal çaba göstermek ya da rol yapmak zorunda olmadıkları ve işin yapısı gereği duruma uygun doğal davranışlar sergilemelerine yardımcı olan adalet algısı etkileşim adaletidir. Buna göre temel hakları temin etme ve korumada dağıtım adaleti önemli bir işleve sahipken, esas ve içsel motivasyon yaratan adalet boyutu etkileşim adaletidir.

Buna göre araştırma amaçları doğrultusunda ortaya atılan çok boyutlu hipotezden " $\mathbf{H}_{\mathbf{1}}$ : Örgütsel adalet algısının dağıtım adaleti alt boyutu duygusal emeğin yüzeysel, derin ve doğal rol davranışı üzerinde etkilidir." Kısmen kabul edilirken(yüzeysel rol davranışı ve derin rol davranışı), " $\mathbf{H}_{2}$ : Örgütsel adalet algısının işlem adaleti alt boyutu duygusal emeğin yüzeysel, 
derin ve doğal rol davranışı üzerinde etkilidir." ve "H. Örgütsel adalet algısının etkileşim adaleti alt boyutu duygusal emeğin yüzeysel, derin ve doğal rol davranışı üzerinde etkilidir." reddedilmiştir.

Duygusal emek kavramı birçok örgütsel çıktı ile (iş tatmini, tükenmişlik, işten ayrılma, işte kalma niyeti, örgütsel bağlılık, örgütsel güven, örgütsel vatandaşlık, sinizm, stres, performans vb.) ele alınmış olmasına karşın alan yazında örgütsel adalet ile duygusal emek arasındaki ilişkinin incelendiği araştırma sayısı yok denecek kadar azdır. Emek ve duygusal sermayenin büyük önem arz ettiği, insan ilişkilerinin yoğun yaşandığ 1 sağlık hizmetleri sektöründe duygu işçilerinin davranışlarının şekillendirilmesinde örgütsel adalet algısının nasıl bir etkiye sahip olduğunun belirlendiği bu araştırmanın yönetici ve uygulayıcılara katkı sağlayacağı umulmaktadır.

Örgütlerin amaç ve hedeflerine ulaşabilmeleri için çalışanları ile bütünleşmeleri elzemdir. $\mathrm{Bu}$ anlamda çalışanların hissettikleri duygular ile örgütün kendilerinden beklediği duygular arasındaki farkı azaltacak tedbirlerin alınması önemlidir. Çalışanların uzun süreli maruz kalacakları adaletsiz tutum ve davranışlar onları duygu-davranış karmaşasına sürükleyerek onların iş-yaşam dengelerine zarar verebilir. Bu anlamda örgütsel yapı ve politikalar aracılığ 1 ile bir kültür haline getirilecek olan adalet algısının güçlendirilmesi önemli görülmektedir. Örgütlerinin kendilerine karşı adaletli bir tutum izlediğine inanan çalışanların duyguları ile davranışları arasındaki fark azalarak yüzeysel rol davranışından uzaklaşacakları söylenebilir. Duygu ve davranış arasındaki farkın ortadan kalkması doğal rol davranışının ortaya çıkmasına zemin hazırlamaktadır. Çalışanlar zorunlu oldukları için değil, inandıkları ve istedikleri için davranışta bulunduklarında bireysel ve örgütsel çıktıların daha sağlıklı ve olumlu olacağı düşünülebilir. Yine çalışanların örgütsel adalet algılarını yükseltmek ve duygu-davranış uyumlarını sağlamak adına insan odaklı yönetsel yaklaşımlar benimsenmelidir. Kaynak, ödül, ceza, bilgi, yetki ve güç gibi çalışanlar için önem arz eden unsurların dağılımında adil bir yaklaşım sergilenmesi önemlidir.

$\mathrm{Bu}$ çalışma Nevşehir il merkezinde faaliyet gösteren kamu hastanesine bağlı 112 acil servis istasyonları çalışanları üzerine yapılmıştır. Araştırmanın bu kısıtının ortadan kaldırılabilmesi için farklı sektör ve amaçlara sahip örgüt çalışanları üzerine karşılaştırmalı bir çalışma yapılması alana önemli katkılar sağlayacaktır. Yine farklı değişkenlerin duygusal emek üzerindeki etkisinin belirlenmesi hizmet sektörünün kalitesini arttıracaktır.

\section{Kaynakça}

Akbıyık, M. (2013). Etkili liderliğin duygusal emek davranışları üzerindeki etkisi hizmet sektöründe bir uygulama. Yüksek Lisans Tezi. Ege Üniversitesi. İzmir.

Ali, N., \& Jan, S. (2012). Relationship between organizational justice and organizational commitment and turnover intentions amongst medical representatives of pharmaceuticals companies of Pakistan. Journal of Managerial Sciences, 6(2), 201-212.

Aquino, K., Lewis, M. U., \& Bradfield, M. (1999). Justice constructs, negative affectivity, and employee deviance: A proposed model and empirical test. Journal of Organizational Behavior, 20, 1073-1091. 
Arslantaş, C., \& Pekdemir, I. (2007). Dönüşümcü liderlik, örgütsel vatandaşlık davranışı ve örgütsel adalet arasındaki ilişkileri belirlemeye yönelik görgül bir araştırma, Anadolu Üniversitesi Sosyal Bilimler Dergisi, 7(1), 261-286.

Ashforth, B., \& Humphrey, R. (1993). Emotional labor in service roles: The influence of identity. Academy of Management Review, 18, 88-115.

Ashforth, B., \& Humprey, R. (1995). Emotion in the workplace: A reappraisal. Human Relations, 48(2), 97-125.

Barling, J., \& Michelle, P. (1993). Interactional, formal and distributive justice in theworkplace: An exploratory study. Journal of Psychology, 127(6), 649-656.

Basım, H. N., \& Beğenirbaş, M. (2012). Çalışma yaşamında duygusal emek: Bir ölçek uyarlama çalışması. Celal Bayar Üniversitesi İktisadi ve İdari Bilimler Fakültesi Yönetim ve Ekonomi Dergisi, 19(1), 77-90.

Begley, T. M., Lee, C., \& Hui, C. (2006). Organizational level as a moderator of the relationship between justice perceptions. Journal of Organizational Behaviour, 27, 705-721.

Barger, P. B., \& Grandey, A. A. (2006). Service with a smile and encounter satisfaction: Emotional contagion and appraisal mechanisms. Academy of Management Journal, 49(6), 1229-1238.

Bos, K. V. D. (2001). Fundamental research by means of laboratory experiments is essential for a beter understanding of organizational justice. Journal of Vocational Behaviour, 58, 254-259.

Brotheridge, C. M., \& Grandey, A. A. (2002). Emotional labor and burnout: Comparing two perspectives of "people work". Journal of Vocational Behavior, 60(1), 17-39.

Chu, K. H. L., \& Murrmann, S. K. (2006). Development and validation of the hospitality emotional labor scale. Tourism Management, 27(6), 1181-1191.

Colquitt, A. J., Conlon, D. E., Wesson, M. J., Porter, O. L. H., \& Yee Ng, K. (2001). Justice at the millennium. A meta-analytic review of 25 years of organizational justice research. Journal of Applied Psychology, 86(3), 425-445.

Colquitt, J.A. (2001). On the dimensionality of organizational justice: A construct validation of a measure. Journal of Applied Psychology, 86, 386-400.

Colquitt, J. A., \& Chertkoff, J. M. (2002). Explaining injustice: The interactive effect of explanati on and outcome on fairness perceptions and task motivation. Journal of Management, 28(5), 591-610.

Colquitt, J. A. \& Rodell, J. B. (2011). Justice, trust and trustworthiness: A longitudinal analysis integrating three theoretical Perspekctives. Academy of Management, 54(6), 1183-1206.

Çaldağ, M. A. (2010). Duygusal emek davranışlarının să̆lık çalışanlarında iş sonuçlarına etkileri. Yüksek Lisans Tezi. Selçuk Üniversitesi. Konya.

Çetinkaya, M., \& Çimenci, S. (2014). Örgütsel adalet algısının örgütsel vatandaşlık davranışı üzerindeki etkisi ve örgütsel özdeşleşmenin aracılık rolü: Yapısal eşitlik modeli çalışması. Yönetim Bilimleri Dergisi, 12(23), 237-278.

Çokluk, Ö., Şekercioğlu, G., \& Büyüköztürk, Ş. (2010). Sosyal bilimler için çok değişkenli istatistik: SPSS ve LISREL uygulamaları. Pegem Akademi. 
DeConinck, J. B. (2010). The effect of organizational justice, perceived organizational support, and perceived supervisor support on marketing employees' level of trust. Journal of Business Research, 63(12), 1349-1355.

Değirmenci, S. (2010). Hemşirelerin duygusal emek davranışı ve etkileyen faktörler. Yüksek Lisans Tezi. İstanbul Üniversitesi, İstanbul.

Diefendorff, J. M., Croyle, M. H. \& Grosserand R. H. (2005). The dimensionality and antecedents of emotinal labor strategies. Journal of Vocational Behavior, 66, 339-357.

Eker, G. (2006). Örgütsel adalet algısı boyutları ve iş doyumu üzerindeki etkileri. Yüksek lisans tezi, Dokuz Eylül Üniversitesi, Sosyal Bilimler Enstitüsü, İzmir.

Folger, R. \& Konovsky, M.A. (1989). Effects of procedural and distributive justice on reactions to pay raise decisions. Academy of Management Journal, 32(1), 115-130.

Glomb, T. M., Kammeyer-Mueller, J. D., \& Rotundo, M. (2004). Emotional labor demands and compensating wage differentials. Journal of Applied Psychology, 89(4), 700-714.

Grandey, A., Fisk, G. M. \& Steiner, D. D. (2005). Must service with a smile be stressful? The moderating role of personal control for US and French employees. Journal of Applied Psychology, 90(5), 893-904.

Grandey,A. (2003). When the show must go on: Surface acting and deep acting as determinants of emotional exhaustion and peer-rated service delivery. Academy of Management Journal, 46, 86-96.

Grandey, A. A. (2000). Emotion regulation in the workplace: A new way to conceptualize emotional labor. Journal of Ocupational Health Psychology, 5(1), 10.

Greenberg, J. (1987). A taxonomy of organizational justice theories. The Academy of Management Review, 12(1), 9-21.

Greenberg, J. (1990). Employee theft as a reaction to underpayment inequity: The hidden cost of pay cuts. Journal of Applied Psychology, 75(5), 561-568.

Greenberg, J. (1993). Justice and organizational citizenship: A commentary on the state of the science. Employee Responsibilities and Rights Journal, (6)3, 249-256.

Greenberg, J. (2001). The seven loose can (n)ons of organizational justice.

In J. Greenberg, R. Cropanzano (Eds.), Advances in Organizational Justice. California: Stanford University Press.

Gross, J. (1998). The emerging field of emotion regulation: An integrative review. Review of General Psychology, 2(3), 271-299.

Güngör, M. (2009). Duygusal emek kavramı: süreci ve sonuçları. Kamu-İş, 11(1), 167-184.

Hess, U. (2003). Emotion at work rapport Bourgogne. Erişim tarihi: 20/05/2016, CIRANO, Montreal, Qc. http://www.cirano.qc.ca/pdf/publication/2003RB-03.pdf

Hochschild,A. R. (1983). The managed hearth: Commercialization of human feeling. Berkeley, CA: University of California Press.

Hochschild, A. R. (2003). The managed heart: Commercialization of human feeling. Berkeley: University of California Press. 
İçerli, L. (2010). Örgütsel adalet: Kuramsal bir yaklaşım. Journal of Entrepreneurship and Development, 5(1), 67-92.

İşcan, Ö. F. \& Naktiyok, A. (2004). Çalışanların örgütsel bağdaşımlarının belirleyicileri olarak örgütsel bağlılık ve örgütsel adalet algıları. Ankara Üniversitesi Siyasal Bilgiler Fakïltesi Dergisi, 59(1), 181-201.

İşcan, Ö. F. \& Sayın, U.. (2010). Örgütsel adalet, iş tatmini ve örgütsel güven arasındaki ilişki. Atatürk Üniversitesi İktisadi ve İdari Bilimler Dergisi, 24(4), 195-216.

Jones, D. A. (2009). Getting even with one's supervisor and one's organization: relationships among types of injustice, desires for revenge, and counterproductive work behaviors. Journal of Organizational Behavior, 30, 525-542.

Kalaycı, Ş. (2010). SPSS Uygulamalı çok değişkenli istatistik teknikleri. 5. Baskı, Ankara: Asil Yayın Dağıtım.

Keleş, Y., \& Tuna, M. (2016). Örgütsel adaletin duygusal emek üzerindeki etkisi: Antalya'daki beş yıldızlı otel işletmelerinde bir araştırma. İşletme Araştırmaları Dergisi, 8(2), 376407.

Keleş, Y. (2014). Örgütsel adaletin duygusal emek üzerindeki etkisi: Antalya'daki beş yıldızlı otel işletmelerinde bir araştırma. Doktora tezi, Eğitim Bilimleri Enstitüsü, Ankara.

Kızanlıklı, M. (2014). Otel işletmelerinde duygusal emek öncüllerinin belirlenmesine yönelik bir araştırma. Doktora Tezi. Gazi Üniversitesi, Ankara.

Kickul, J., Gundry L. K. \& Posig, M. (2005). Does trust matter? The relationship between equity sensitivity and perceived organizational justice. Journal of Business Ethics, 56, 205-218.

Köksel, L. (2009). İş yaşamında duygusal emek ve ampirik bir çalışma. Yayınlanmamış Yüksek lisans tezi, Celal Bayar Üniversitesi Sosyal Bilimler Enstitüsü. Manisa

Kruml, S. M., \& Geddes, D. (2000). Exploring the dimension of emotional labor: The heart of Hochschild, work. Management Communication Quarterly, 14, 8-49.

Lam, W. \& Chen, Z. (2012). When I put on my service mask: Determinants and outcomes of emotional labour among hotel service providers according to affective event theory. International Journal of Hospitality Management. 31, 311.

Leventhal, G. S. (1980). What should be done wity equity theory?, In K. J. Gergen, M. S. Greenberg, R. H. Willis (Eds.), Social exchanges: Advances in theory and research (pp. 27-55). New York: Plenum.

Malatesta, R. M., \& Byrne, Z. S. (1997). The impact of formal and interactional justice on organizational outcomes. Twelfth Annual Conference of the Society forIndustrial and Organizational Psychology, April, St. Louis, MO.

Martinez-Inigo, D., Totterdell, P., Alcover, C. M., \& Holman, D. (2007). Emotional labour and emotional exhaustion: Interpersonal and intrapersonal mechanisms. Work and Stress, 21(1), 30-47.

Moon, T. W., Hur, W. M. \& Jun, J. K. (2013). The role of perceived organizational support on emotional labor in the airline industry. International Journal of Contemporary Hospitality Management, 25(1), 105-123. 
Moorman, R. H. (1991). Relationship between organizational justice and organizational citizenship behaviors: Do fairness pereeptions influence employee citizenship?. Journal of Applied Psychology, 76(6), 845-855.

Morris, J. A., \& Feldman, D. C. (1996). The dimensions, antecedents, and consequences of emotional labor. Academy of Management Review, 21, 986-1010.

Niehoff, B. P., \& Moorman, R. H. (1993). Justice as a mediator of the relationship between methods of monitoring and organizational citizenship behavior. Academy of Management Journal, 36(3), 527-556.

Organ, D. W. (1988). O.C.B.: The good soldier syndrome. Lexington: Lexington Book.

Öz, E. Ü. (2007). Duygusal emek davranışlarının çalışanların iş sonuçlarına etkisi. İstanbul: Beta.

Özdamar, K. (2011). Paket programlar ile istatistiksel veri analizi. Eskişehir: Kaan Kitabevi.

Özdevecioğlu, M. (2003). Algılanan örgütsel adaletin bireylerarası saldırgan davranışlar üzerindeki etkilerinin belirlenmesine yönelik bir araştırma. Erciyes Üniversitesi İktisadi ve İdari Bilimler Fakültesi Dergisi, 21, 77-96.

Özmen, N. T., Arbak, Y., \& Özer, P. S. (2007). Adalete verilen değerin adalet algıları üzerindeki etkisinin sorgulanmasına ilişkin bir araştırma. Ege Akademik Bakış, 7(1), 17-33.

Polat, S. (2007). Ortaögretim ögretmenlerinin örgütsel adalet alglları, örgütsel güven düzeyleri ile örgütsel vatandaşlık davranışları arasındaki ilişki.Doktora tezi, Kocaeli Üniversitesi, Kocaeli.

Robbins, S. P., \& Judge, T. A. (2012). Essentials of organizational behavior. 16. Baskl, New Jersey: Pearson Education.

Rupp, D. E., \& Spencer, S. (2006). When customers lash out: The effects of customer interactional injustice on emotional labor and the mediating role of discrete emotions. Journal of Applied Psychology, 91(4), 971-978.

Rupp, D. E., McCance, A. S., Spencer, S., \& Sonntag, K. (2008). Customer (in) justice and emotional labour: The role of perspective taking, anger, and emotional regulation. Journal of Management, 34(5), 903-924.

Schmiesing, R. J., Safrit, R. D., \& Gliem J. A. (2003). Factors affecting O.S.U. extension agents' preceptions of organizational justice and job satisfaction. Journal of International Agricultural and Extansion Education, 10(2), 25-32.

Simons, T., \& Roberson, Q. (2003). Why managers should care about fairness: The effects of aggregate justice perceptions on organizational outcomes. Journal of Applied Psychology, 88(3), 432-443.

Skarlicki, D. P., \& Folger, R. (1997). Retaliation in the workplace: The roles of distributive procedural, and interactional justice. Journal of Applied Psychology, 82(3), 434-443.

Şengül, A. (2009). Hizmet işletmelerinde yüksek ilişki kalitesine ulaşılmasında sınır birim işgörenlerinin duygu işçisi olarak değerlendirilmesi. Ege Akademik Bakış, 9(4), 1193 1211. 
Tang, C., Seal,C.R., \& Naumann,S.E. (2013). Emotional labor strategies, customer cooperation and buying decisions. Journal of Management and Marketing Research, 13, 1-15.

Thomas, P., \& Nagalingappa, G. (2012). Consequences of perceived organizational justice: An empirical study of white-collar employees. Journal of Arts, Science and Commerce, 3(2), 54-63.

Yazıcıoğlu, İ., \& Topaloğlu, I. G. (2009), Örgütsel adalet ve bağlılık ilişkisi: Konaklama işletmelerinde bir uygulama. İşletme Araştırmaları Dergisi, 1(1), 3-16.

Yıldız, S. (2014). Örgütsel adaletin örgütsel vatandaşlık davranışına etkisinde iş tatmininin aracılık rolü. Ege Akademik Bakış, 14(2), 199-210.

Yürür, S., Gümüş, M. \& Hamarat, B. (2011). Çalışan-müşteri ilişkilerinde algılanan adalet/ adaletsizliğin duygusal emek davranışlarına etkisi. Journal of Yasar University, 20(6), 3826-3839. 